\title{
The Impact of Trade Facilitation on Vietnam's Trade Flows
}

DOI: 10.14456/ajmi.2020.10

ajmi.stamford.edu

Received: December 12, 2019

Revised: May 26, 2020

Accepted: June 22, 2020

\section{Zhen Yu}

Department of World Economics, Wuhan University, China.

Yuzhenwhu@126.com

\section{Boito Luu}

Department of World Economics, Wuhan University, China.

Cathy_lau88@yahoo.com.vn

\begin{abstract}
In today's globalized economy, countries actively participate in Free Trade Agreements (FTAs) in order to bring their advantageous products to the global market through cross-border trade. The extent of the benefits of FTAs though is largely of function of the level of implementation of the trade facilitation (TF) measures contained in these agreements as simplified customs procedures and improved customs clearance efficiency can help traders substantially reduce their costs. This paper focuses on Vietnam which has been active in the last two decades expanding its trade linkages with various countries around the world. Due to these international trade arrangements, Hanoi has been committed to implementing TF measures agreed upon. The purpose of this paper is to determine the impact of TF measures on Vietnam's trade flows during the period 2007-2018 in two cases; in the presence of FTAs and with no FTA concluded. Vietnam's import and export data sets from that period ara analyzed using the gravity model and the Generalized Method of Moments (GMM). The results show that during that period TF had a positive impact on Vietnam's trade flows and that its affect was consistent with and without FTAs. Since TF implementation is still at a relatively early stage, when TF reforms really take place, reduced trade costs are likely to further increase trade volume. In short, TF has gradually become major factors of trade growth.
\end{abstract}

Keywords: Free Trade Agreement, Trade Facilitation, Vietnam's bilateral Trade Flows, Economic Benefits.

\section{Introduction}

Vietnam's economy has been on an upward trajectory for over a decade thanks in no small part to the policies implemented under the so-called "Đổi Mới" - the Vietnamese term used to describe Vietnam's economic reforms from the early 1990s onward. Focusing on the modernization of the agricultural and industrialization sectors, all the measures taken to transition from a state economy to some forms of market economy have steadily raised the country's Gross Domestic Product (GDP) (Pham \& Vuong, 2009; Vuong \& Napier, 2014). Also contributing to the country's rising living standards is its accession to the 10-member Association of South East Asian Nations (ASEAN) on July 28, 1995. Among other benefits, it has led to the elimination of tariffs on most ASEAN-originating goods traded across the region and made Vietnamese products cheaper across the trade bloc, promoting Vietnamese trade in the process. Vietnam's trade linkages are not, however, simply limited to Southeast Asian nations. Over the last 15 years, Hanoi has been expanding its network of preferential trading partners, both collectively, negotiating as part of ASEAN as one unit (ASEAN+1), and individually, negotiating its own bilateral agreements with various countries around the world (unlike members of the European Union who can only negotiate collectively, ASEAN member states can enter into bilateral accords on their own). According to the Vietnam Chamber of Commerce and Industry (VCCI), as of 2019, Vietnam has concluded 16 free Agreements 
(FTAs) both collectively and individually. FTAs bring many preferential tariff benefits to participating members (Vuong, Semerak, \& Vuong, 2019) and have had a positive impact on Vietnam's import and export flows. During the period 2007-2018, both the country's imports and exports increased exponentially. As shown in Figure 1, however, trade with FTA partners grew more rapidly than with non-FTA partners, rising from USD400 million in 2006 to USD1.6 billion in 2018. Clearly, FTAs provide Vietnam with more trade opportunities. Preferential Trade Arrangements (PTA) not only substantially

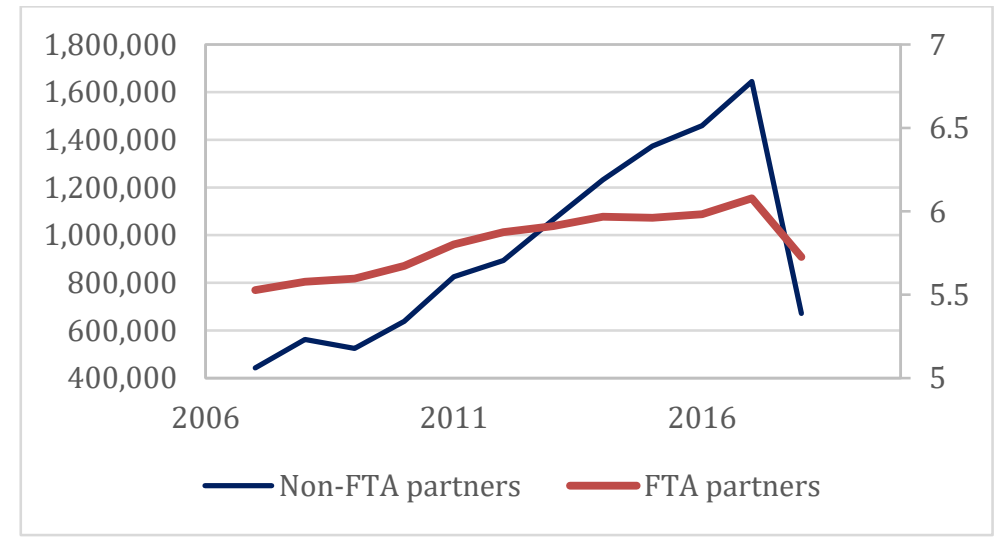

Figure 1: Vietnam's Total Import-Export Value (Mil.USD) Source: General Statistics Office of Vietnam

reduce or eliminate tariffs, they also facilitate trade by eliminating non-tariff barriers. Indeed, trade facilitation (TF) measures are an integral part of trade negotiations. There is, however, no standard definition of $\mathrm{TF}$ as its scope is determined by FTA negotiations (Asian Development Bank-ADB \& United Nations Economic and Social Commission for Asia and the Pacific-UNESCAP, 2009). According to Chauffour and Maur (2011), the biggest benefit of TF is the reduction of transaction costs, which in turn increases job opportunities and income generation, thereby promoting economic development (Ramos, Zarzoso, \& Suarez-Burgest, 2012; Herzer, 2013; Sakyi, Villaverde, \& Maza, 2015). In the medium and long term, TF has a positive impact on improving trade capacity as it increases foreign direct investment and enhances the participation of domestic enterprises in the global supply chains (ADB \& UNESCAP, 2013). Customs procedural reform can shave off $2.8 \%$ of the trade costs for middle-income countries and 2.2\% for low-income countries (Moïsé \& Sorescu; 2013).

Although Vietnam has become one economy relatively open, the complexity and lack of transparency of customs border processes and inconsistent regulations have created many challenges in improving the competitive environment. The problem is rooted in specialized inspection, which as part of the customs clearance procedures, is carried out by functional ministries. The result is that different types of Vietnamese specialized inspections relate to many ministries, which significantly delay customs clearance and create unnecessary costs to importers and exporters. According to Doing Business (2016) statistics, the amount of time needed to import goods into Vietnam and comply with all kinds of inspection requirements (documentary compliance) amount to 76 hours as compared to 3 hours in Singapore as shown in Table 1. As to border compliance, it adds up to 56 hours, versus 33 hours in Singapore. In the meantime, the amount of time needed to export goods amounts to 50 hours of documentary compliance and 55 hours of border compliance. This is still the case in spite of Hanoi's commitment to the World Trade Organization (WTO) and the WTO Trade Facilitation Agreement (TFA) and a host of FTAs. As noted earlier, Vietnam is slowly implementing its international obligations but while the country has policies, plans and projects, they are not 
linked together (Pham et al., 2013). This creates instability for investors and businesses. Hollweg and Wong (2009) examined the differences in the logistics regulatory environment of ASEAN+6 economies and concluded that the countires that have the most limited logistic services in the ASEAN+6 area are China, Indonesia, Laos, Malaysia, Philippines, and Vietnam.

Table 1: Time Required for Export/Import of Goods within ASEAN (hours) in 2016

\begin{tabular}{|c|c|c|c|c|}
\hline & \multicolumn{2}{|c|}{ Export Time } & \multicolumn{2}{|c|}{ Import Time } \\
\hline & $\begin{array}{c}\text { Border } \\
\text { compliance }\end{array}$ & $\begin{array}{c}\text { Documentary } \\
\text { compliance }\end{array}$ & $\begin{array}{c}\text { Border } \\
\text { compliance }\end{array}$ & $\begin{array}{l}\text { Documentary } \\
\text { compliance }\end{array}$ \\
\hline VNM & 55 & 50 & 56 & 76 \\
\hline THA & 44 & 11 & 50 & 4 \\
\hline SGP & 10 & 2 & 33 & 3 \\
\hline PHL & 42 & 36 & 120 & 96 \\
\hline MMR & 142 & 144 & 230 & 48 \\
\hline MYS & 28 & 10 & 36 & 7 \\
\hline LAO & 9 & 60 & 11 & 60 \\
\hline IDN & 53.3 & 61.3 & 99.4 & 106.2 \\
\hline $\mathrm{KMH}$ & 45 & 132 & 8 & 132 \\
\hline BRN & 117 & 155 & 48 & 132 \\
\hline
\end{tabular}

Source: Doing business (2016). VNM, Vietnam; THA, Thailand; SGP, Singapore; PHL, Philipines; MMR: Myanmar; LAO, Laos, IDN, Indonesia; KMH, Cambodia; BRN, Brunei.

This paper seeks to examine the impact of TF on Vietnam's trade flows during the period 2007-2018. More specifically, using the gravity model and the Generalized Method of Moments (GMM) method, it considers the impact of TF on Vietnam's trade flows either with or without the presence of FTAs. TF for the purpose of this research is defined through 4 effects, i.e. customs effect (CE), regulatory effect (RE), port effect (PE) and infrastructure effect (IE), which are aggregated through different indicators. The paper is organized as follows: Section 2 provides an overview of the research literature on TF. Section 3 examines the methodology and presents the variables used in this paper. The results of the impact of TF on Vietnam's trade flows are then shown in Section 4 and discussed in Section 5. This paper concludes in Section 6 , which also provides policy recommendations.

\section{Key Concepts}

\section{- Trade Facilitation (TF)}

As noted in the introduction, TF measures are integral to the negotiation process and commonly regarded as an indispensable part of trade negotiations and the conclusion of Preferential trade arrangements. TF is a key issue for national economic growth (OECD, 2017). There is, however, no standard definition of FT as its scope varies with the scale of the measures adopted in negotiated trade agreements (ADB \& UNESCAP, 2009). TF can nevertheless broadly be defined as a range of trade measures (Chauffour \& Maur, 2011). It can thus be said that TF consists in reducing procedural barriers, implementing cooperation, and coordinating between governmental and inter-governmental border agencies (Goldin \& Reinert, 2007). In other words, TF is a series of port efficiency, transport issues or measures designed to simplify the requirements of cross-border trading systems (Wilson, Mann, \& Otsuki, 2004). The extent of the measures involved has gradually expanded over time (Chauffour \& Maur, 2011). Their main purpose is to ensure the quick release and clearance of goods in order to accelerate the flow of goods, imports and transportation (Jordaan, 2004). As traders seek the best strategies to reduce their trade costs and transfer quality products to other parts of the world for further trade, TF contributes to a reduction in import and export costs as well as a surge in global trade 
(Organization for Economic Co-operation and Development-OECD, 2018). The 1996 WTO's Trade Facilitation Agreement (WTA) has created important opportunities to increase the speed and efficiency of border processes. However, although the WTF has received the support of most countries, its implementation has been uneven. Logistics is closely related to TF, especially border management processes and customs procedures (Korinek \& Sourdin, 2011). With the growing importance of global supply chains, the need to simplify the application procedure is of priority for all countries. In this paper, Yet, while WTO members have gradually improved their logistics policies, many of the policies adopted are not strictly enforced (Nguyen, Nguyen, \& Hoang, 2016).

\section{- TF's Economic Benefits}

In recent years, there have been much research on the economic benefits of TF (Ramos et al., 2012; Herzer, 2013; Sakyi et al., 2015; Ramanayake \& Lee, 2015). It is widely acknowledged that TF increases trade flows and brings cheaper goods to the rest of the world as it reduces trade costs through the demolition of trade barriers (Dollar \& Kraay, 2004; Ramos et al., 2012; Tuffour et al., 2016). TF increases both import and export activities (Ramanayake \& Lee, 2015) and ensures a higher predictability of transaction processes (Dreger \& Herzer, 2013), therefore increasing national competitiveness. By reducing trading costs, TF increases participation in global value chains that characterize today's international trade. TF is thus an important growth factor. It not only capital increases investment but also reduces poverty (Ravallion, 2001; Dollar \& Kraay, 2004; Winters et al., 2004; Sakyi et al., 2017). Enterprises use the best price of the goods to transfer them to the world in the shortest time and fastest speed. In the process of trade transactions, minimizing trade barriers and trade costs will promote more exports and imports. TF, however, may have knock-on effect on economic activity, employment opportunities, competition, education, health and technology transfer if TF measures are not fully implemented and enforced (Heshmati \& Peng, 2012; Herzer, 2013; Sakyi et al., 2015). The burden is multiplied for small and medium enterprises (SMEs) because most of them are less aware of new regulations and have less access to new technologies (Ramanayake \& Lee, 2015). Wilson (2003) measured the impact TF on economic development using port effect, regulatory effect, customs effect and e-business. Otsuki (2011) assessed the benefits of TF by looking at the port environment, regulatory environment, customs environment, and the service sector infrastructure. In this research paper, TF is therefore defined through four effects: customs effect (CE), regulatory effect (RE), port effect (PE) and infrastructure effect (IE). As detailed in the next section, each of them includes a number of indicators.

\section{- The Gravity Model}

The basic gravity model explains the export size of country $i$ to country $j$ on the basis of three factors: the total export capacity of country $i$, the import demand of the country $j$, and various elements likely to constrain trade flows between countries (Cheewatrakoolpong \& Rujanakanoknad, 2011). The gravity model is a popular approach to model bilateral trade flows. Tinbergen (1962) and Pöyhönen (1963), for example, used the gravity model to explain the bilateral trade flows of various European trading partners. The gravity model was also used by Jordaan (2014) to consider the impact of TF factors on South African exports to African countries. Wilson (2003) examined the relationship between TF and trade flows with GDPs per capita in the Asia-Pacific region through the prism of the gravity model and concluded that improvements in customs and e-business utilization significantly expanded trade, albeit to a lesser degree than efficient ports or regulations would. Cheewatrakoolpong and Rujanakanoknad (2011) looked at the impact of the improvement of TF on Thai transportation and trade within ASEAN. The results indicate that compliance with the implementation of TF reforms is effective in improving Thailand's export value. Some studies combined the gravity model and the Computable General Equilibrium (CGE) model to quantify the benefits of 
improved TF (e.g. UNCTAD, 2001; Fox, Francois, \& Londono-Kent, 2003). For instance, Hertel, Walmsley, and Itakura (2001) used a CGE analysis to measure the impact of standard harmonization in e-business and automated customs procedures on trade and concluded that reforms contributed to increasing trade flows between countries. Walkenhorst and Yasui (2003) estimated the benefits of reducing trade transaction costs based on the CGE model as did Walmsley and Minor (2016). Both studies determined that customs efficiency is needed to increase the benefits of trade.

Some research papers have also used the Generalized Method of Moments (GMM) to assess the impact of TF on trade. For example, Sakyi et al. (2017) used the GMM method to determine the impact of TF on trade and economic growth in Africa and on the welfare of African countries (Sakyi et al., 2018). These results contributed to confirming previous findings showing that the improvement of the customs and legal environment in importing countries as well as their domestic infrastructure generally increase trade flows. To determine the TF impact on Vietnam's trade flows during the period 2007-2018 with or without the presence of FTAs, this paper used the gravity model and the System-GMM method to eliminate endogeneity problems.

\section{Measuring the Impact of Vietnam's Trade Facilitation - Estimation Model}

This section focuses on the research methodology adopted in this study. It explains the empirical method employed and the variables used based on the four effects through which TF is defined. It is important to note first that the values used in this paper are the average values of the various indicators through which the four effects are aggregated. It is also worth noting that different studies have included different structural elements to the basic gravity model so as to better reflect reality. For example, Wilson (2003) included tariffs and other standard variables, Otsuki, Wilson, and Sewadeh (2001a, 2001b) used fixed effects to control price differences and unobservable factors. The model used in this research study, however, uses less data. Although a bit more rudimentary, it is more applicable to developing countries where price data is less reliable and incomplete. Therefore, the estimation model used in this paper is a gravity model that includes Vietnam's TF and trade partners as well as the GDP of the countries considered. Three additional parameters included in the equation distinguish countries in three ways: those that have preferential trade arrangments with Vietnam from those that do not, those that have a common language, and those are adjacent as opposed to distant. As Jordaan (2004) pointed out, when two countries use English as their primary language of communication, this can translate into trading advantages. In addition, when two trading partners enjoy geographical advantages, the latter will increase the exports and imports of both countries. Therefore, the estimated model used in this research paper is provided by the following equation:

$$
\begin{gathered}
\operatorname{lnTradeflow}_{\mathrm{ijt}}=\beta_{0}+\beta_{1} \operatorname{lnTF}_{\mathrm{ijt}}+\beta_{3} \operatorname{lnGDP}_{\mathrm{it}}+\beta_{4} \operatorname{lnGDP}_{\mathrm{jt}}+\operatorname{lnDIST} \mathrm{Iij}_{\mathrm{ij}}+\ln \mathrm{D}_{\mathrm{FTA}}+ \\
\operatorname{lnD_{\text {lang}}}+\ln \mathrm{D}_{\mathrm{Adj}}+\varepsilon_{\mathrm{ijt}}
\end{gathered}
$$

Where:

- $t$ denotes the transaction year from 2007 to 2018. The reason for choosing this research period is because 2007 is the year Vietnam joined the World Trade Organization (WTO). Among other benefits, accession to the WTO provided Vietnam with opportunities to conclude FTAs with a number of nations around the world, including with ASEAN and its main partners in Asia-Pacific, and the United States and the European Union. As to 2018, 
at the time this research was conducted, it was the last year that data from sources such as the World Bank and the General Statistics office of Vietnam were published and available.

- Tradeflowijt represents the value of exports and imports from country $i$ to $j$ and vice versa, for a period of time $t$.

- $i$ represents Vietnam and $j$ Vietnam's trading partner.

- $\mathrm{TF}_{\mathrm{ijt}}$ stands for customs and regulatory effects and port efficiency, infrastructure effects.

- GDP G $_{\text {it }}$ and GDP $_{\mathrm{jt}}$ denote the gross national product of $i$ and $\mathrm{j}$ in time $t$.

- DIST $T_{i j}$ represents the geographical distance between the Vietnam's capital city and that of its trading partners. As noted earlier, TF is a two-way activity. It is not only an effort by trading partners to reduce or eliminate uncessary and burdensome border procedures, but also a similar cooperative effort by Vietnam to facilitate and speed up customs clearance. Therefore, each TF indicator will be the average TF of both Vietnam and its trading partners.

- DFta, Dlang, $D_{\text {Adj }}$ are the dummy variables, where DFTA has a value of 1 for countries with

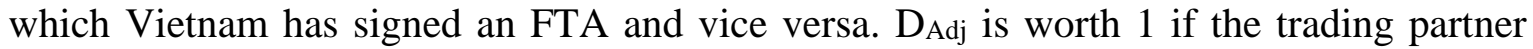
country is adjacent to Vietnam. In an opposite situation, it is 0 .

As we just saw above, in this paper TF is defined through four effects : customs effect (CE), regulatory effect $(\mathrm{RE})$, port effect $(\mathrm{PE})$ and infrastructure effect (IE). They all relate to the efficiency of customs procedures, clearance, transparency (or the lack thereof), and the burden of an inflation of legal documents and bureaucratic management. These four effects tend to increase the cost and time of cross-border commodity transactions. These four effects are aggregated through various indicators as follows:

- Customs Effect (CE) - The data for this indicator is based on the Global Enabling Trade Report (GETR) and includes:

- Burden of customs procedures

- Customs services index

- Regulatory Effect $(R E)$ - This indicator averages the following six index inputs from the Worldwide Governance Indicators (WGI) and the World Bank World Development Indicators (WB WDI):

- Control of Corruption

- Government Effectiveness

- Regulatory Quality

- Rule of Law

- CPIA business regulatory environment rating

- CPIA policy and institutions for environmental sustainability rating

- Port Effect $(P E)$ - Each country's PE aggregates inputs from the Liner Shipping Connectivity Index (LSCI) and the Global Enabling Trade Report (GETR) as follows:

- Effectiveness and efficiency of clearance

- Liner Shipping Connectivity Index. This indicator includes transshipments, common direct connections, geometric means of direct connections, level of competition in shipping services, and ships size.

- Infrastructure Effect (IE) - Each country's IE indicator consists of three inputs from the Global Competitiveness Report (GCR) and the World Bank World Development Indicators (WB WDI) :

- Quality of port infrastructure

- Quality of trade and transport-related infrastructure

- Efficiency of customs clearance process 
Table 2 shows the mean and standard deviation of the indicators of these four effects TF as described above.

Table 2: Descriptive Statistics of TF Indicators

\begin{tabular}{llcccc}
\hline Category & Indexed input & Mean & Std.Dev. & Min & Max \\
\hline CE & Burden of customs procedures & .287680 & .150036 & 0 & 1 \\
& Customs services index & .356525 & .136883 & 0 & 1 \\
RE & Control of Corruption & .591515 & .184324 & 0 & 1 \\
& Government Effectiveness & .583956 & .181555 & 0 & 1 \\
& Regulatory Quality & .622336 & .175799 & 0 & 1 \\
& Rule of Law & .643190 & .177562 & 0 & 1 \\
& CPIA business regulatory environment rating & .351525 & .402477 & 0 & 1 \\
& CPIA policy and institutions for environmental & .336548 & .370695 & 0 & 1 \\
& Sustainability rating & & & & \\
PE & Effectiveness and efficiency of clearance & .292529 & .173672 & 0 & 1 \\
& Liner Shipping Connectivity Index & .291099 & .166349 & 0 & 1 \\
& Quality of port infrastructure & .540538 & .211306 & 0 & 1 \\
& Quality of trade and transport related infrastructure & .273302 & .123652 & 0 & 1 \\
& Efficiency of customs clearance process & .428815 & .174589 & 0 & 1 \\
\hline
\end{tabular}

Source: Compiled by author based on WGI, GETR, WB WDI, GCR and LSCI

\section{- Data Sources}

The import and export data used in this study were obtained from the General Statistics Office of Vietnam. They covered the period 2007-2018. As we just saw, the indicators through which the CE, RE, PE and IE variables were aggregated were collected from annual survey results published on the WGI, GETR, GCR, and LSCI. The GDP value was computed based on data provided by the Vietnam Statistics Office and the World Bank. Moreover, the geographic distance data between Vietnam and its trading partners was compiled based on Geodatasoure database; a complete database of latitude and longitude coordinates and regional and national information on 249 countries or territories on 6 continents. The adjacency value was determined via Googlemap and FTA data provided by Vietnam Chamber of Commerce and Industry (VCCI). Table 3 describes the variables used for this analysis and their sources.

Table 3: Variables Defined and Data Sources

\begin{tabular}{|c|c|c|}
\hline Variable & Definition & Source \\
\hline \multicolumn{3}{|l|}{ Dependent Variables } \\
\hline Vietnam's exports & Value of exports from Vietnam to trading partners & GSOV \\
\hline Vietnam's imports & Value of import from to trading partners & GSOV \\
\hline \multicolumn{3}{|l|}{ Main Variables } \\
\hline \multicolumn{3}{|l|}{ TF indicators } \\
\hline \multirow[t]{2}{*}{$\mathrm{CE}$} & Burden of customs procedures & GETR \\
\hline & Customs Services index & GETR \\
\hline \multirow[t]{5}{*}{$\mathrm{RE}$} & Control of corruption & WB WGI \\
\hline & Government effectiveness & WB WGI \\
\hline & Regulatory quality & WB WGI \\
\hline & Rule of law & WB WGI \\
\hline & CPIA business regulatory environment rating & WB WDI \\
\hline
\end{tabular}




\begin{tabular}{|c|c|c|}
\hline $\begin{array}{l}\text { January } \\
2020\end{array}$ & ASEAN JOURNAL OF MANAGEMENT \& INNOVATION & \\
\hline & CPIA policy and institutions for environmental sustainability rating & WB WDI \\
\hline $\mathrm{PE}$ & Effectiveness and efficiency of clearance & GETR \\
\hline & Liner Shipping Connectivity Index & LSCI \\
\hline IE & Quality of port infrastructure & GCR \\
\hline & Quality of trade and transport related infrastructure & WB WDI \\
\hline & Efficiency of customs clearance process & WB WDI \\
\hline GDPi & Gross national product of Vietnam & GSOV \\
\hline GDPj & Gross national product of trading partners & WB WDI \\
\hline Control Varia & & \\
\hline Distance & Distance between Vietnam and trading partners & Geodatasoure \\
\hline FTA & Bilateral FTAs with Vietnam, it has a value of 1 and vice versa & VCCI \\
\hline Language & English as first language, it has a value of 1 and vice versa & Wikipedia \\
\hline Adjacency & If partner country is neighboring country, the value is 1 and vice versa & Google map \\
\hline
\end{tabular}

\section{Estimates of Impact on Vietnam's Trade Flows}

This section presents the results of the application of the empirical model to Vietnam's exports and imports. The empirical results are presented in Tables 3 through 8, where Tables 3 and 4 show the baseline specification results, Tables 5 and 6, the TF impact on Vietnam's export flows in terms of fixed effect, and Tables 7 and 8, the empirical results of the System-GMM regression. Table 9 shows the robustness check results. As explained earlier, the main variable of interest for this analysis is the TF variable, which is reported through four main variables/indicators: $\mathrm{CE}, \mathrm{RE}, \mathrm{PE}$ and IE. Each table includes the results of 12 empirical models as follows:

- models (1-3) present the CE impact on Vietnam's exports and imports;

- models (4-6), the RE impact;

- models (7-9), the PE impact; and

- models (10-12), the IE impact.

Tables 3 and 4 present the baseline specification results. They show how TF impacts Vietnam's exports and imports. Table 3 focuses on the TF impact on export flows and Table 4 on its impact on import flows. Models 1, 4, 7, 10 in those two tables show the value of four TF indicators without FTA variables. It can be seen that the variables are positive and statistically significant. Models 2, 5, 8 and 11 show the value of four TF indicators in the presence of FTAs. As is the case when there is no FTA, these variables are positive and statistically significant both in terms of output and input flows. Models 3, 6, 9 and 12 show the impact of TF indicators in the concomitant presence of the following four factors: FTAs, geography, language, and distance. Again, the results are positive for both Vietnam's export and import flows. The four TF coefficients in the export and import flows are positive with the import flow of Vietnam at the $\mathrm{p}$-value of $1 \%$. However, the CE variables in both tables bear the (-) sign. This shows that customs issues have not yet been fully dealt with, which results in delays in the clearance process and negatively affects Vietnam's export and import flows.

Tables 5 and 6 show the results of the effects of four TF coefficients on export and import flows. This analysis used the fixed-effect model to analyze trade between Vietnam and its trading partners. The Hausman test was performed to confirm the random and fixed effects, which were consistent with this analysis. The Hausman test shows a p-value of 0.0167 . Since p-value $<0.05$, this research paper chooses the fixed effects model as the main model to analyze the impact of TF on trade flows between Vietnam and trading partners. The RE, PE and IE 
variables are positive and statistically significant. The $\mathrm{CE}$ variable, however, is not statistically significant. As with the previous analysis in Tables 3 and 4, the RE, PE and IE coefficients do not change significantly in the presence of FTAs. This is not saying though that Vietnam's conclusion of FTAs does not benefit the economy; it does. The TF indicators, however, do not show it clearly. A third approach in this study, one meant to eliminate endogeneity problems due to the correlation between explanatory variables and error terms, is to use the SystemGMM estimation tool, which is based on a large cross-section and a small-time dimension. Tables 7 and 8 outline the results of this method. As with the previous four tables, the results are also arranged in 12 models. Models 1-3 show the results of the CE variable, models 4-6 the results of the RE variable, models 7-9 the results of the variable PE and models 10-12 those of the IE variable. Save for the CE variable, whose results are the opposite of those shown in the previous tables, all the other results in those two tables are similar to the previous tables and therefore positive and statistically significant. At 1\%, the impact a 5.043 percent RE improvement will increase exports by 0.749 percent and Vietnam's GDP by 0.521 percent. The impact of the TF is also evident on the import side as a 4.734 percent improvement of the RE will increase imports by 0.687 percent and increase Vietnam's GDP by 0.618 percent. Using the System-GMM method, the results show that Vietnam's import and export are affected by TF. In general, the impact of TF on Vietnam's trade is positive and statistically significant. The results are not much different when Vietnam's trade linkages are taken into account. There is no difference when distance, adjacency and language are part of the equation. Again while the importance of these variables cannot be denied, in this particular analysis, they seem to have no clear impact.

Finally, to test the robustness of the empirical model, the TF indicator was replaced by the following four indicators : Cost to import, border compliance (USD); Cost to export, documentary compliance (USD); Cost to export, border compliance (USD); and Cost to import, documentary compliance (USD). The estimated sample was also determined for the period 2007-2018. TF improves individual well-being as it reduces trade costs and therefore directly reduces the final price that people pay for the goods they consume (World Bank, 2017). The variable TF is the average of the four cost variables related to exports and imports. Therefore, the TF variable is predicted to have a (-) sign.

Table 9 shows the results of the estimation of the impact of TF on Vietnam's imports and exports. The table consists of 6 models; models (1-3) show the TF impact on Vietnam's exports and models (4-6), its impact on Vietnam's imports. Through these models, the TF impact can be seen clearly. There is a real export flow as the TF coefficients, below the p-value of $1 \%$ are positive and statistically significant in models (1) and (2). There is no difference when FTAs have been concluded between trading partners, which means that the improvement of Vietnam's $\mathrm{TF}$ is not due to the existence FTAs. The implication is that TF is an essential element for improving Vietnam's trade flows. As predicted above, the sign of the TF coefficient is negative, although there is no clear sign on the import side of Vietnam but the (-) sign of the TF coefficient indicates that countries' customs effects will negatively affect import and export flows, Vietnam's exports in particular.

To summarize, during the period 2007-2018, the impact of TF on Vietnam's export flows is clear and positive. However, there is no clear impact on Vietnam's import flows. In addition, TF increases Vietnam's trade flows, regardless of the existence of FTAs, whose presence has no effect. These finidngs are entirely consistent with previous studies (e.g. Wilson, 2003; Wilson et al., 2004; Chauffour \& Maur, 2011; Jordaan, 2014). 
Table 3: TF Impact on Vietnam's Export Flows (Baseline Specification)

\begin{tabular}{|c|c|c|c|c|c|c|c|c|c|c|c|c|}
\hline & (1) & (2) & (3) & (4) & (5) & (6) & (7) & (8) & (9) & (10) & (11) & (12) \\
\hline $\mathrm{CE}$ & $\begin{array}{c}-3.183 * * * \\
(1.006)\end{array}$ & $\begin{array}{c}-3.141 * * * \\
(1.000)\end{array}$ & $\begin{array}{c}-3.345^{* * *} \\
(0.974)\end{array}$ & & & & & & & & & \\
\hline $\mathrm{RE}$ & & & & $\begin{array}{c}6.020 * * * \\
(0.707)\end{array}$ & $\begin{array}{c}6.107 * * * \\
(0.689)\end{array}$ & $\begin{array}{c}5.872 * * * \\
(0.697)\end{array}$ & & & & & & \\
\hline $\mathrm{PE}$ & & & & & & & $\begin{array}{c}9.345^{* * *} \\
(0.360)\end{array}$ & $\begin{array}{c}9.705^{* * * *} \\
(0.456)\end{array}$ & $\begin{array}{c}9.596 * * * \\
(0.433)\end{array}$ & & & \\
\hline IE & & & & & & & & & & $\begin{array}{c}4.397 * * * \\
(0.856)\end{array}$ & $\begin{array}{c}4.232 * * * \\
(0.871)\end{array}$ & $\begin{array}{c}3.875^{* * *} * \\
(0.880)\end{array}$ \\
\hline GDPit & $\begin{array}{c}1.638 * * * \\
(0.323)\end{array}$ & $\begin{array}{c}1.634 * * * \\
(0.292)\end{array}$ & $\begin{array}{c}1.641 * * * \\
(0.284)\end{array}$ & $\begin{array}{c}2.037 * * * \\
(0.298)\end{array}$ & $\begin{array}{c}2.038 * * * \\
(0.265)\end{array}$ & $\begin{array}{c}2.003 * * * \\
(0.261)\end{array}$ & $\begin{array}{c}-1.921 * * * \\
(0.285)\end{array}$ & $\begin{array}{c}-2.056 * * * \\
(0.287)\end{array}$ & $\begin{array}{c}-2.029 * * * \\
(0.278)\end{array}$ & $\begin{array}{c}0.862 * * * \\
(0.310)\end{array}$ & $\begin{array}{c}0.877 * * * \\
(0.280)\end{array}$ & $\begin{array}{c}0.909 * * * \\
(0.277)\end{array}$ \\
\hline GDPjt & $\begin{array}{c}3.43 \mathrm{e}- \\
05^{* * *} \\
(6.14 \mathrm{e}-06)\end{array}$ & $\begin{array}{c}3.45 \mathrm{e}- \\
05^{* * *} \\
(6.12 \mathrm{e}-06)\end{array}$ & $\begin{array}{c}3.79 \mathrm{e}- \\
05^{* * * *} \\
(6.00 \mathrm{e}-06)\end{array}$ & $\begin{array}{c}5.32 \mathrm{e}- \\
05 * * * \\
(5.73 \mathrm{e}-06)\end{array}$ & $\begin{array}{c}5.58 \mathrm{e}- \\
05 * * * \\
(5.94 \mathrm{e}-06)\end{array}$ & $\begin{array}{c}5.72 \mathrm{e}- \\
05^{* * *} \\
(5.95 \mathrm{e}-06)\end{array}$ & $\begin{array}{l}5.16 \mathrm{e}-06^{*} \\
(2.98 \mathrm{e}-06)\end{array}$ & $\begin{array}{c}6.61 \mathrm{e}- \\
06^{* *} \\
(3.24 \mathrm{e}-06)\end{array}$ & $\begin{array}{c}9.72 \mathrm{e}- \\
06 * * * \\
(3.13 \mathrm{e}-06)\end{array}$ & $\begin{array}{c}-1.19 \mathrm{e}-06 \\
(7.70 \mathrm{e}-06)\end{array}$ & $\begin{array}{c}9.06 \mathrm{e}-07 \\
(7.95 \mathrm{e}-06)\end{array}$ & $\begin{array}{c}5.48 \mathrm{e}-06 \\
(8.12 \mathrm{e}-06)\end{array}$ \\
\hline FTA & $\mathrm{N}$ & $\mathrm{Y}$ & $\mathrm{Y}$ & $\mathrm{N}$ & Y & Y & $\mathrm{N}$ & $\mathrm{Y}$ & Y & $\mathrm{N}$ & $\mathrm{Y}$ & Y \\
\hline language & $\mathrm{N}$ & $\mathrm{N}$ & $\mathrm{Y}$ & $\mathrm{N}$ & $\mathrm{N}$ & $\mathrm{Y}$ & $\mathrm{N}$ & $\mathrm{N}$ & Y & $\mathrm{N}$ & $\mathrm{N}$ & $\mathrm{Y}$ \\
\hline Distance & $\mathrm{N}$ & $\mathrm{N}$ & $\mathrm{Y}$ & $\mathrm{N}$ & $\mathrm{N}$ & $\mathrm{Y}$ & $\mathrm{N}$ & $\mathrm{N}$ & $\mathrm{Y}$ & $\mathrm{N}$ & $\mathrm{N}$ & $\mathrm{Y}$ \\
\hline adjacency & $\mathrm{N}$ & $\mathrm{N}$ & $\mathrm{Y}$ & $\mathrm{N}$ & $\mathrm{N}$ & $\mathrm{Y}$ & $\mathrm{N}$ & $\mathrm{N}$ & Y & $\mathrm{N}$ & $\mathrm{N}$ & $\mathrm{Y}$ \\
\hline Constant & $\begin{array}{l}-1.407 \\
(2.725)\end{array}$ & $\begin{array}{l}-1.831 \\
(2.456)\end{array}$ & $\begin{array}{c}-6.914 * * * \\
(2.464)\end{array}$ & $\begin{array}{c}-9.682 * * * \\
(2.699)\end{array}$ & $\begin{array}{c}-10.21 * * * \\
(2.434)\end{array}$ & $\begin{array}{c}-12.80 * * * \\
(2.351)\end{array}$ & $\begin{array}{c}26.06 * * * \\
(2.360)\end{array}$ & $\begin{array}{c}26.84 * * * \\
(2.356)\end{array}$ & $\begin{array}{c}23.98 * * * \\
(2.308)\end{array}$ & $\begin{array}{c}3.056 \\
(2.588)\end{array}$ & $\begin{array}{c}2.492 \\
(2.327)\end{array}$ & $\begin{array}{l}-1.191 \\
(2.434)\end{array}$ \\
\hline $\mathrm{R}^{2}$ & 0.117 & 0.297 & 0.337 & 0.239 & 0.418 & 0.438 & 0.455 & 0.535 & 0.559 & 0.165 & 0.337 & 0.358 \\
\hline $\begin{array}{l}\text { No. of } \\
\text { Name }\end{array}$ & 73 & 73 & 73 & 73 & 73 & 73 & 73 & 73 & 73 & 73 & 73 & 73 \\
\hline
\end{tabular}

Note: Robust standard errors in parentheses. $* * * \mathrm{p}<0.01, * * \mathrm{p}<0.05, * \mathrm{p}<0.1$ 
Table 4: TF impact on Vietnam's Import Flows (Baseline Specification)

\begin{tabular}{|c|c|c|c|c|c|c|c|c|c|c|c|c|}
\hline & (1) & (2) & (3) & (4) & (5) & (6) & (7) & (8) & (9) & (10) & (11) & (12) \\
\hline $\mathrm{CE}$ & $\begin{array}{c}-7.291 * * * \\
(0.933)\end{array}$ & $\begin{array}{c}-7.211 * * * \\
(0.872)\end{array}$ & $\begin{array}{c}-7.406 * * * \\
(0.845)\end{array}$ & & & & & & & & & \\
\hline RE & & & & $\begin{array}{c}8.174 * * * \\
(0.825)\end{array}$ & $\begin{array}{c}8.104 * * * \\
(0.753)\end{array}$ & $\begin{array}{c}7.977 * * * \\
(0.758)\end{array}$ & & & & & & \\
\hline $\mathrm{PE}$ & & & & & & & $\begin{array}{c}9.708 * * * \\
(0.428)\end{array}$ & $\begin{array}{c}8.468 * * * \\
(0.521)\end{array}$ & $\begin{array}{c}8.421 * * * \\
(0.505)\end{array}$ & & & \\
\hline IE & & & & & & & & & & $\begin{array}{c}4.003 * * * \\
(1.001)\end{array}$ & $\begin{array}{c}3.875 * * * \\
(0.985)\end{array}$ & $\begin{array}{c}3.553 * * * \\
(1.003)\end{array}$ \\
\hline GDPit & $\begin{array}{c}1.621 * * * \\
(0.378)\end{array}$ & $\begin{array}{c}1.608 * * * \\
(0.305)\end{array}$ & $\begin{array}{c}1.613 * * * \\
(0.296)\end{array}$ & $\begin{array}{c}1.904 * * * \\
(0.357)\end{array}$ & $\begin{array}{c}1.878 * * * \\
(0.283)\end{array}$ & $\begin{array}{c}1.854 * * * \\
(0.280)\end{array}$ & $\begin{array}{c}-2.422 * * * \\
(0.368)\end{array}$ & $\begin{array}{c}-2.003 * * * \\
(0.342)\end{array}$ & $\begin{array}{c}-1.998 * * * * \\
(0.335)\end{array}$ & $\begin{array}{c}0.533 \\
(0.388)\end{array}$ & $\begin{array}{l}0.536^{*} \\
(0.321)\end{array}$ & $\begin{array}{l}0.562 * \\
(0.318)\end{array}$ \\
\hline GDPjt & $\begin{array}{c}6.47 \mathrm{e}- \\
05^{* * *} \\
(6.02 \mathrm{e}-06)\end{array}$ & $\begin{array}{c}6.61 \mathrm{e}- \\
05 * * * \\
(5.86 \mathrm{e}-06)\end{array}$ & $\begin{array}{c}6.98 \mathrm{e}- \\
05^{* * *} \\
(5.74 \mathrm{e}-06)\end{array}$ & $\begin{array}{c}8.31 \mathrm{e}- \\
05^{* * *} \\
(6.31 \mathrm{e}-06)\end{array}$ & $\begin{array}{c}8.76 \mathrm{e}- \\
05 * * * \\
(6.17 \mathrm{e}-06)\end{array}$ & $\begin{array}{c}8.96 \mathrm{e}- \\
05 * * * \\
(6.18 \mathrm{e}-06)\end{array}$ & $\begin{array}{c}2.48 \mathrm{e}- \\
05 * * * \\
(3.55 \mathrm{e}-06)\end{array}$ & $\begin{array}{c}3.19 \mathrm{e}- \\
05^{* * *} \\
(3.94 \mathrm{e}-06)\end{array}$ & $\begin{array}{c}3.51 \mathrm{e}- \\
05 * * * \\
(3.86 \mathrm{e}-06)\end{array}$ & $\begin{array}{c}2.18 \mathrm{e}-05^{* *} \\
(8.80 \mathrm{e}-06)\end{array}$ & $\begin{array}{c}2.58 \mathrm{e}- \\
05^{* * *} \\
(8.90 \mathrm{e}-06)\end{array}$ & $\begin{array}{c}3.04 \mathrm{e}- \\
05 * * * \\
(9.16 \mathrm{e}-06)\end{array}$ \\
\hline FTA & $\mathrm{N}$ & $\mathrm{Y}$ & Y & $\mathrm{N}$ & $\mathrm{Y}$ & $\mathrm{Y}$ & $\mathrm{N}$ & $\mathrm{Y}$ & Y & $\mathrm{N}$ & $\mathrm{Y}$ & Y \\
\hline language & $\mathrm{N}$ & $\mathrm{N}$ & $\mathrm{Y}$ & $\mathrm{N}$ & $\mathrm{N}$ & Y & $\mathrm{N}$ & $\mathrm{N}$ & Y & $\mathrm{N}$ & $\mathrm{N}$ & Y \\
\hline Distance & $\mathrm{N}$ & $\mathrm{N}$ & $\mathrm{Y}$ & $\mathrm{N}$ & $\mathrm{N}$ & $\mathrm{Y}$ & $\mathrm{N}$ & $\mathrm{N}$ & Y & $\mathrm{N}$ & $\mathrm{N}$ & $\mathrm{Y}$ \\
\hline adjacency & $\mathrm{N}$ & $\mathrm{N}$ & $\mathrm{Y}$ & $\mathrm{N}$ & $\mathrm{N}$ & $\mathrm{Y}$ & $\mathrm{N}$ & $\mathrm{N}$ & Y & $\mathrm{N}$ & $\mathrm{N}$ & Y \\
\hline Constant & $\begin{array}{l}-1.543 \\
(3.185)\end{array}$ & $\begin{array}{l}-2.229 \\
(2.556)\end{array}$ & $\begin{array}{c}-7.088 * * * \\
(2.563)\end{array}$ & $\begin{array}{c}-11.29 * * * \\
(3.232)\end{array}$ & $\begin{array}{c}-11.82 * * * \\
(2.606)\end{array}$ & $\begin{array}{c}-13.29 * * * \\
(2.580)\end{array}$ & $\begin{array}{c}28.99 * * * \\
(3.062)\end{array}$ & $\begin{array}{c}25.03 * * * \\
(2.815)\end{array}$ & $\begin{array}{c}22.81 * * * \\
(2.812)\end{array}$ & $\begin{array}{c}4.724 \\
(3.247)\end{array}$ & $\begin{array}{c}3.901 \\
(2.657)\end{array}$ & $\begin{array}{c}0.871 \\
(2.817)\end{array}$ \\
\hline $\mathrm{R}^{2}$ & 0.260 & 0.538 & 0.565 & 0.316 & 0.589 & 0.601 & 0.387 & 0.544 & 0.560 & 0.169 & 0.450 & 0.463 \\
\hline $\begin{array}{l}\text { No. of } \\
\text { Name }\end{array}$ & 73 & 73 & 73 & 73 & 73 & 73 & 73 & 73 & 73 & 73 & 73 & 73 \\
\hline
\end{tabular}

Note: Robust standard errors in parentheses. $* * * \mathrm{p}<0.01, * * \mathrm{p}<0.05, * \mathrm{p}<0.1$ 
Table 5: TF Impact on Vietnam's Export Flows (Fixed-effect)

\begin{tabular}{|c|c|c|c|c|c|c|c|c|c|c|c|c|}
\hline & (1) & (2) & (3) & (4) & (5) & (6) & (7) & (8) & (9) & (10) & (11) & (12) \\
\hline $\mathrm{CE}$ & $\begin{array}{c}1.320 \\
(1.175)\end{array}$ & $\begin{array}{c}1.320 \\
(1.175)\end{array}$ & $\begin{array}{c}1.343 \\
(1.182)\end{array}$ & & & & & & & & & \\
\hline $\mathrm{RE}$ & & & & $\begin{array}{c}1.836^{* * * *} \\
(0.271)\end{array}$ & $\begin{array}{c}1.836 * * * \\
(0.271)\end{array}$ & $\begin{array}{c}1.835^{* * * *} \\
(0.271)\end{array}$ & & & & & & \\
\hline PE & & & & & & & $\begin{array}{c}2.819 * * * \\
(0.579)\end{array}$ & $\begin{array}{c}2.819 * * * \\
(0.579)\end{array}$ & $\begin{array}{c}2.855^{* * * *} \\
(0.580)\end{array}$ & & & \\
\hline IE & & & & & & & & & & $\begin{array}{l}1.729 * * \\
(0.835)\end{array}$ & $\begin{array}{l}1.729^{* * *} \\
(0.835)\end{array}$ & $\begin{array}{l}1.727 * * * \\
(0.834)\end{array}$ \\
\hline GDPit & $\begin{array}{c}1.293^{* * *} \\
(0.195)\end{array}$ & $\begin{array}{c}1.293 * * * \\
(0.195)\end{array}$ & $\begin{array}{c}1.300 * * * \\
(0.198)\end{array}$ & $\begin{array}{c}1.613 * * * \\
(0.189)\end{array}$ & $\begin{array}{c}1.613 * * * \\
(0.189)\end{array}$ & $\begin{array}{c}1.619^{* * *} \\
(0.194)\end{array}$ & $\begin{array}{c}0.430 \\
(0.307)\end{array}$ & $\begin{array}{c}0.430 \\
(0.307)\end{array}$ & $\begin{array}{c}0.430 \\
(0.308)\end{array}$ & $\begin{array}{c}1.176^{* * *} \\
(0.186)\end{array}$ & $\begin{array}{c}1.176^{* * *} \\
(0.186)\end{array}$ & $\begin{array}{c}1.183^{* * * *} \\
(0.191)\end{array}$ \\
\hline GDPjt & $\begin{array}{c}1.14 \mathrm{e}-05 \\
(1.15 \mathrm{e}-05)\end{array}$ & $\begin{array}{c}1.14 \mathrm{e}-05 \\
(1.15 \mathrm{e}-05)\end{array}$ & $\begin{array}{c}1.23 \mathrm{e}-05 \\
(1.18 \mathrm{e}-05)\end{array}$ & $\begin{array}{l}2.27 \mathrm{e}-05^{*} \\
(1.33 \mathrm{e}-05)\end{array}$ & $\begin{array}{l}2.27 \mathrm{e}-05^{*} \\
(1.33 \mathrm{e}-05)\end{array}$ & $\begin{array}{l}2.33 \mathrm{e}-05^{*} \\
(1.38 \mathrm{e}-05)\end{array}$ & $\begin{array}{c}4.75 \mathrm{e}-06 \\
(1.09 \mathrm{e}-05)\end{array}$ & $\begin{array}{c}4.75 \mathrm{e}-06 \\
(1.09 \mathrm{e}-05)\end{array}$ & $\begin{array}{c}5.94 \mathrm{e}-06 \\
(1.14 \mathrm{e}-05)\end{array}$ & $\begin{array}{c}1.28 \mathrm{e}-05 \\
(1.15 \mathrm{e}-05)\end{array}$ & $\begin{array}{c}1.28 \mathrm{e}-05 \\
(1.15 \mathrm{e}-05)\end{array}$ & $\begin{array}{c}1.34 \mathrm{e}-05 \\
(1.18 \mathrm{e}-05)\end{array}$ \\
\hline FTA & $\mathrm{N}$ & $\mathrm{Y}$ & Y & $\mathrm{N}$ & $\mathrm{Y}$ & Y & $\mathrm{N}$ & $\mathrm{Y}$ & $\mathrm{Y}$ & $\mathrm{N}$ & $\mathrm{Y}$ & $\mathrm{Y}$ \\
\hline language & $\mathrm{N}$ & $\mathrm{N}$ & $\mathrm{Y}$ & $\mathrm{N}$ & $\mathrm{N}$ & $\mathrm{Y}$ & $\mathrm{N}$ & $\mathrm{N}$ & $\mathrm{Y}$ & $\mathrm{N}$ & $\mathrm{N}$ & $\mathrm{Y}$ \\
\hline Distance & $\mathrm{N}$ & $\mathrm{N}$ & $\mathrm{Y}$ & $\mathrm{N}$ & $\mathrm{N}$ & $\mathrm{Y}$ & $\mathrm{N}$ & $\mathrm{N}$ & $\mathrm{Y}$ & $\mathrm{N}$ & $\mathrm{N}$ & $\mathrm{Y}$ \\
\hline adjacency & $\mathrm{N}$ & $\mathrm{N}$ & $\mathrm{Y}$ & $\mathrm{N}$ & $\mathrm{N}$ & $\mathrm{Y}$ & $\mathrm{N}$ & $\mathrm{N}$ & $\mathrm{Y}$ & $\mathrm{N}$ & $\mathrm{N}$ & $\mathrm{Y}$ \\
\hline Constant & $\begin{array}{c}0.777 \\
(1.482)\end{array}$ & $\begin{array}{c}0.777 \\
(1.482)\end{array}$ & $\begin{array}{c}390.4 \\
(638.2)\end{array}$ & $\begin{array}{l}-2.895^{*} \\
(1.721)\end{array}$ & $\begin{array}{l}-2.895^{*} \\
(1.721)\end{array}$ & $\begin{array}{c}242.2 \\
(545.6)\end{array}$ & $\begin{array}{c}7.897 * * * \\
(2.414)\end{array}$ & $\begin{array}{c}7.897 * * * \\
(2.414)\end{array}$ & $\begin{array}{c}554.2 \\
(474.4)\end{array}$ & $\begin{array}{c}1.298 \\
(1.393)\end{array}$ & $\begin{array}{c}1.298 \\
(1.393)\end{array}$ & $\begin{array}{l}260.0 \\
(501.3)\end{array}$ \\
\hline $\mathrm{R}^{2}$ & 0.240 & 0.240 & 0.240 & 0.297 & 0.297 & 0.297 & 0.258 & 0.258 & 0.259 & 0.259 & 0.259 & 0.259 \\
\hline No. of Name & 73 & 73 & 73 & 73 & 73 & 73 & 73 & 73 & 73 & 73 & 73 & 73 \\
\hline
\end{tabular}

Note: Robust standard errors in parentheses. $* * * \mathrm{p}<0.01, * * \mathrm{p}<0.05, * \mathrm{p}<0.1$ 
Table 6: TF Impact on Vietnam's Import Flows (Fixed-effect)

\begin{tabular}{|c|c|c|c|c|c|c|c|c|c|c|c|c|}
\hline & (1) & (2) & (3) & (4) & (5) & (6) & (7) & (8) & (9) & (10) & (11) & (12) \\
\hline $\mathrm{CE}$ & $\begin{array}{c}1.264 \\
(0.944)\end{array}$ & $\begin{array}{c}1.264 \\
(0.944)\end{array}$ & $\begin{array}{l}1.248 \\
(0.947)\end{array}$ & & & & & & & & & \\
\hline $\mathrm{RE}$ & & & & $\begin{array}{c}1.242 * * * \\
(0.287)\end{array}$ & $\begin{array}{c}1.242 * * * \\
(0.287)\end{array}$ & $\begin{array}{c}1.244 * * * \\
(0.287)\end{array}$ & & & & & & \\
\hline PE & & & & & & & $\begin{array}{l}1.151^{* * *} \\
(0.563)\end{array}$ & $\begin{array}{l}1.151^{* *} \\
(0.563)\end{array}$ & $\begin{array}{l}1.134^{* *} \\
(0.567)\end{array}$ & & & \\
\hline IE & & & & & & & & & & $\begin{array}{l}1.118^{*} \\
(0.573)\end{array}$ & $\begin{array}{l}1.118^{*} \\
(0.573)\end{array}$ & $\begin{array}{l}1.121 * \\
(0.573)\end{array}$ \\
\hline GDPit & $\begin{array}{c}1.152 * * * \\
(0.144)\end{array}$ & $\begin{array}{c}1.152 * * * \\
(0.144)\end{array}$ & $\begin{array}{c}1.147 * * * \\
(0.146)\end{array}$ & $\begin{array}{c}1.406 * * * \\
(0.156)\end{array}$ & $\begin{array}{c}1.406 * * * \\
(0.156)\end{array}$ & $\begin{array}{c}1.396 * * * \\
(0.160)\end{array}$ & $\begin{array}{c}0.872 * * * \\
(0.236)\end{array}$ & $\begin{array}{c}0.872 * * * \\
(0.236)\end{array}$ & $\begin{array}{c}0.872 * * * \\
(0.237)\end{array}$ & $\begin{array}{c}1.118 * * * \\
(0.148)\end{array}$ & $\begin{array}{c}1.118 * * * \\
(0.148)\end{array}$ & $\begin{array}{c}1.108 * * * \\
(0.152)\end{array}$ \\
\hline GDPjt & $\begin{array}{c}-2.88 \mathrm{e}-05^{* * * *} \\
(9.34 \mathrm{e}-06)\end{array}$ & $\begin{array}{c}-2.88 \mathrm{e}-05 * * * \\
(9.34 \mathrm{e}-06)\end{array}$ & $\begin{array}{c}-2.94 \mathrm{e}-05^{* * *} * \\
(9.38 \mathrm{e}-06)\end{array}$ & $\begin{array}{c}-2.14 \mathrm{e}-05^{*} \\
(1.16 \mathrm{e}-05)\end{array}$ & $\begin{array}{c}-2.14 \mathrm{e}-05^{*} \\
(1.16 \mathrm{e}-05)\end{array}$ & $\begin{array}{c}-2.23 \mathrm{e}-05^{*} \\
(1.17 \mathrm{e}-05)\end{array}$ & $\begin{array}{c}-3.20 \mathrm{e}- \\
05 * * * \\
(9.01 \mathrm{e}-06)\end{array}$ & $\begin{array}{c}-3.20 \mathrm{e}- \\
05^{* * *} \\
(9.01 \mathrm{e}-06)\end{array}$ & $\begin{array}{c}-3.26 \mathrm{e}-05^{* * *} \\
(9.09 \mathrm{e}-06)\end{array}$ & $\begin{array}{c}-2.81 \mathrm{e}- \\
05^{* * *} \\
(9.44 \mathrm{e}-06)\end{array}$ & $\begin{array}{c}-2.81 \mathrm{e}- \\
05^{* * *} \\
(9.44 \mathrm{e}-06)\end{array}$ & $\begin{array}{c}-2.90 \mathrm{e}-05 * * * * \\
(9.46 \mathrm{e}-06)\end{array}$ \\
\hline FTA & $\mathrm{N}$ & $\mathrm{Y}$ & $\mathrm{Y}$ & $\mathrm{N}$ & $\mathrm{Y}$ & $\mathrm{Y}$ & $\mathrm{N}$ & $\mathrm{Y}$ & $\mathrm{Y}$ & $\mathrm{N}$ & $\mathrm{Y}$ & $\mathrm{Y}$ \\
\hline language & $\mathrm{N}$ & $\mathrm{N}$ & $\mathrm{Y}$ & $\mathrm{N}$ & $\mathrm{N}$ & $\mathrm{Y}$ & $\mathrm{N}$ & $\mathrm{N}$ & $\mathrm{Y}$ & $\mathrm{N}$ & $\mathrm{N}$ & $\mathrm{Y}$ \\
\hline Distance & $\mathrm{N}$ & $\mathrm{N}$ & $\mathrm{Y}$ & $\mathrm{N}$ & $\mathrm{N}$ & $\mathrm{Y}$ & $\mathrm{N}$ & $\mathrm{N}$ & $\mathrm{Y}$ & $\mathrm{N}$ & $\mathrm{N}$ & $\mathrm{Y}$ \\
\hline adjacency & $\mathrm{N}$ & $\mathrm{N}$ & $\mathrm{Y}$ & $\mathrm{N}$ & $\mathrm{N}$ & $\mathrm{Y}$ & $\mathrm{N}$ & $\mathrm{N}$ & $\mathrm{Y}$ & $\mathrm{N}$ & $\mathrm{N}$ & $\mathrm{Y}$ \\
\hline Constant & $\begin{array}{c}2.301 * * \\
(1.127)\end{array}$ & $\begin{array}{c}2.301 * * \\
(1.127)\end{array}$ & $\begin{array}{l}-271.9 \\
(440.7)\end{array}$ & $\begin{array}{l}-0.378 \\
(1.429)\end{array}$ & $\begin{array}{l}-0.378 \\
(1.429)\end{array}$ & $\begin{array}{l}-392.9 \\
(384.1)\end{array}$ & $\begin{array}{c}4.829^{* *} \\
(1.844)\end{array}$ & $\begin{array}{c}4.829 * * \\
(1.844)\end{array}$ & $\begin{array}{l}-250.3 \\
(373.4)\end{array}$ & $\begin{array}{c}2.424 * * \\
(1.136)\end{array}$ & $\begin{array}{c}2.424 * * \\
(1.136)\end{array}$ & $\begin{array}{l}-379.5 \\
(369.0)\end{array}$ \\
\hline $\mathrm{R}^{2}$ & 0.185 & 0.185 & 0.185 & 0.212 & 0.212 & 0.213 & 0.185 & 0.185 & 0.185 & 0.192 & 0.192 & 0.192 \\
\hline No. of Name & 73 & 73 & 73 & 73 & 73 & 73 & 73 & 73 & 73 & 73 & 73 & 73 \\
\hline
\end{tabular}

Note: Robust standard errors in parentheses. $* * * \mathrm{p}<0.01, * * \mathrm{p}<0.05, * \mathrm{p}<0$. 
Table 7: TF Impact of TF Vietnam's Export Flows (System-GMM)

\begin{tabular}{|c|c|c|c|c|c|c|c|c|c|c|c|c|}
\hline & (1) & (2) & (3) & (4) & (5) & (6) & (7) & (8) & (9) & (10) & (11) & (12) \\
\hline $\mathrm{EX}(-1)$ & $\begin{array}{c}1.024 * * * \\
(0.241)\end{array}$ & $\begin{array}{c}1.011^{* * * *} \\
(0.256)\end{array}$ & $\begin{array}{c}1.012 * * * \\
(0.258)\end{array}$ & $\begin{array}{c}0.749 * * * \\
(0.0326)\end{array}$ & $\begin{array}{c}0.724 * * * * \\
(0.0354)\end{array}$ & $\begin{array}{c}0.773 * * * \\
(0.0576)\end{array}$ & $\begin{array}{c}1.982^{* * * *} \\
(0.462)\end{array}$ & $\begin{array}{c}1.974 * * * \\
(0.468)\end{array}$ & $\begin{array}{c}0.482^{* * * *} \\
(0.152)\end{array}$ & $\begin{array}{c}0.803^{* * *} \\
(0.101)\end{array}$ & $\begin{array}{c}0.763^{* * * *} \\
(0.121)\end{array}$ & $\begin{array}{c}0.635 * * * \\
(0.212)\end{array}$ \\
\hline $\mathrm{CE}$ & $\begin{array}{c}21.96 * * * \\
(3.495)\end{array}$ & $\begin{array}{c}21.99 * * * \\
(3.495)\end{array}$ & $\begin{array}{c}21.93 * * * \\
(3.499)\end{array}$ & & & & & & & & & \\
\hline $\mathrm{RE}$ & & & & $\begin{array}{c}5.043 * * * \\
(0.533)\end{array}$ & $\begin{array}{c}5.049 * * * \\
(0.529)\end{array}$ & $\begin{array}{c}3.621 * * * * \\
(0.384)\end{array}$ & & & & & & \\
\hline PE & & & & & & & $\begin{array}{c}-27.04 * * * \\
(9.906)\end{array}$ & $\begin{array}{c}-27.50 * * * \\
(9.748)\end{array}$ & $\begin{array}{c}9.818^{* * * *} \\
(1.093)\end{array}$ & & & \\
\hline IE & & & & & & & & & & $\begin{array}{c}5.181 * * * \\
(1.544)\end{array}$ & $\begin{array}{c}5.386 * * * \\
(1.600)\end{array}$ & $\begin{array}{c}11.67 * * * \\
(1.621)\end{array}$ \\
\hline GDPit & $\begin{array}{c}-2.344 * * * * \\
(0.656)\end{array}$ & $\begin{array}{c}-2.323 * * * \\
(0.670)\end{array}$ & $\begin{array}{c}-2.315^{* * *} \\
(0.667)\end{array}$ & $\begin{array}{c}0.521 * * * * \\
(0.157)\end{array}$ & $\begin{array}{c}2.83 \mathrm{e}-05^{* * * *} \\
(4.82 \mathrm{e}-06)\end{array}$ & $\begin{array}{c}0.120 \\
(0.155)\end{array}$ & $\begin{array}{c}6.456^{* * *} \\
(2.521)\end{array}$ & $\begin{array}{c}6.627 * * * \\
(2.470)\end{array}$ & $\begin{array}{c}-3.315^{* * * *} \\
(0.365)\end{array}$ & $\begin{array}{c}-0.899 * * * \\
(0.191)\end{array}$ & $\begin{array}{c}-0.833^{* * *} \\
(0.219)\end{array}$ & $\begin{array}{c}-1.003 * * * \\
(0.362)\end{array}$ \\
\hline GDPjt & $\begin{array}{c}-6.28 \mathrm{e}- \\
05 * * \\
(1.81 \mathrm{e}-05)\end{array}$ & $\begin{array}{c}-6.26 \mathrm{e}- \\
05 * * * \\
(1.83 \mathrm{e}-05)\end{array}$ & $\begin{array}{c}-6.31 \mathrm{e}-05^{* * * *} \\
(1.86 \mathrm{e}-05)\end{array}$ & $\begin{array}{c}2.79 \mathrm{e}-05^{* * *} \\
(4.54 \mathrm{e}-06)\end{array}$ & $\begin{array}{c}0.341 * * \\
(0.156)\end{array}$ & $\begin{array}{c}2.13 \mathrm{e}-05^{* * * *} \\
(4.37 \mathrm{e}-06)\end{array}$ & $\begin{array}{c}3.69 \mathrm{e}-05^{* *} \\
(1.86 \mathrm{e}-05)\end{array}$ & $\begin{array}{c}3.80 \mathrm{e}-05^{* *} \\
(1.85 \mathrm{e}-05)\end{array}$ & $\begin{array}{c}-7.24 \mathrm{e}-06 \\
(8.45 \mathrm{e}-06)\end{array}$ & $\begin{array}{c}-2.82 \mathrm{e}- \\
05 * * * \\
(9.36 \mathrm{e}-06)\end{array}$ & $\begin{array}{c}-2.85 \mathrm{e}- \\
05^{* * *} \\
(9.22 \mathrm{e}-06)\end{array}$ & $\begin{array}{c}-6.42 \mathrm{e}-05^{* * *} \\
(1.22 \mathrm{e}-05)\end{array}$ \\
\hline FTA & $\mathrm{N}$ & $\mathrm{Y}$ & $\mathrm{Y}$ & $\mathrm{N}$ & $\mathrm{Y}$ & $\mathrm{Y}$ & $\mathrm{N}$ & $\mathrm{Y}$ & Y & $\mathrm{N}$ & Y & Y \\
\hline language & $\mathrm{N}$ & $\mathrm{N}$ & Y & $\mathrm{N}$ & $\mathrm{N}$ & Y & $\mathrm{N}$ & $\mathrm{N}$ & Y & $\mathrm{N}$ & $\mathrm{N}$ & Y \\
\hline Distance & $\mathrm{N}$ & $\mathrm{N}$ & Y & $\mathrm{N}$ & $\mathrm{N}$ & $\mathrm{Y}$ & $\mathrm{N}$ & $\mathrm{N}$ & Y & $\mathrm{N}$ & $\mathrm{N}$ & Y \\
\hline adjacency & $\mathrm{N}$ & $\mathrm{N}$ & $\mathrm{Y}$ & $\mathrm{N}$ & $\mathrm{N}$ & $\mathrm{Y}$ & $\mathrm{N}$ & $\mathrm{N}$ & $\mathrm{Y}$ & $\mathrm{N}$ & $\mathrm{N}$ & $\mathrm{Y}$ \\
\hline Constant & $\begin{array}{c}15.01 * * * \\
(2.676)\end{array}$ & $\begin{array}{c}9.613 * * * \\
(1.035)\end{array}$ & $\begin{array}{c}17.24 * * * \\
(3.637)\end{array}$ & $\begin{array}{c}-4.862^{* * * *} \\
(1.509)\end{array}$ & $\begin{array}{c}-5.081 * * * \\
(1.518)\end{array}$ & $\begin{array}{l}-0.838 \\
(1.313)\end{array}$ & $\begin{array}{c}-60.34 * * \\
(24.19)\end{array}$ & $\begin{array}{c}-61.68 * * * \\
(23.75)\end{array}$ & $\begin{array}{c}31.04 * * * \\
(2.902)\end{array}$ & $\begin{array}{c}8.432^{* * * *} \\
(0.673)\end{array}$ & $\begin{array}{c}8.140 * * * \\
(0.726)\end{array}$ & $\begin{array}{c}10.79 * * * \\
(2.181)\end{array}$ \\
\hline No. of Name & 73 & 73 & 73 & 73 & 73 & 73 & 73 & 73 & 73 & 73 & 73 & 73 \\
\hline $\mathrm{AR}(2)$ & -0.96 & -0.98 & -0.97 & 2.46 & 2.52 & 1.32 & -1.82 & -1.88 & -0.03 & 0.87 & 0.90 & 1.24 \\
\hline $\begin{array}{c}\mathrm{AR}(2) \\
\mathrm{p} \text {-value }\end{array}$ & 0.336 & 0.326 & 0.330 & 0.014 & 0.012 & 0.186 & 0.069 & 0.060 & 0.972 & 0.386 & 0.367 & 0.217 \\
\hline Hansen Stat & 2.67 & 2.72 & 2.80 & 0.85 & 0.83 & 2.87 & 2.30 & 2.31 & 11.01 & 0.22 & 0.14 & 0.24 \\
\hline $\begin{array}{l}\text { Hansen } \\
\text { p-value }\end{array}$ & 0.751 & 0.744 & 0.592 & 0.357 & 0.363 & 0.090 & 0.130 & 0.128 & 0.001 & 0.638 & 0.711 & 0.624 \\
\hline
\end{tabular}

Note: Robust standard errors in parentheses $* * * \mathrm{p}<0.01, * * \mathrm{p}<0.05, * \mathrm{p}<0.1$ 
Table 8: TF Impact on Vietnam's Import Flows (System-GMM)

\begin{tabular}{|c|c|c|c|c|c|c|c|c|c|c|c|c|}
\hline & $(1)$ & $(2)$ & (3) & (4) & $(5)$ & (6) & $(7)$ & (8) & $(9)$ & $(10)$ & $(11)$ & $(12)$ \\
\hline $\operatorname{IM}(-1)$ & $\begin{array}{c}1.086 * * * \\
(0.117)\end{array}$ & $\begin{array}{c}1.115 * * * \\
(0.140)\end{array}$ & $\begin{array}{c}1.380 * * * \\
(0.189)\end{array}$ & $\begin{array}{c}0.740 * * * \\
(0.0428)\end{array}$ & $\begin{array}{c}0.687 * * * \\
(0.0438)\end{array}$ & $\begin{array}{c}0.758 * * * \\
(0.0517)\end{array}$ & $\begin{array}{c}0.641 * * * \\
(0.101)\end{array}$ & $\begin{array}{c}0.635 * * * \\
(0.115)\end{array}$ & $\begin{array}{c}0.545 * * * \\
(0.0770)\end{array}$ & $\begin{array}{c}0.825 * * * \\
(0.0842)\end{array}$ & $\begin{array}{c}0.786 * * * \\
(0.0950)\end{array}$ & $\begin{array}{c}0.775^{* * * *} \\
(0.106)\end{array}$ \\
\hline $\mathrm{CE}$ & $\begin{array}{c}7.597 * * * \\
(2.159)\end{array}$ & $\begin{array}{c}7.691 * * * \\
(2.232)\end{array}$ & $\begin{array}{c}17.01 * * * \\
(3.535)\end{array}$ & & & & & & & & & \\
\hline $\mathrm{RE}$ & & & & $\begin{array}{c}4.734 * * * \\
(0.551)\end{array}$ & $\begin{array}{c}4.753 * * * \\
(0.515)\end{array}$ & $\begin{array}{c}4.049 * * * \\
(0.503)\end{array}$ & & & & & & \\
\hline PE & & & & & & & $\begin{array}{c}9.262 * * * \\
(1.056)\end{array}$ & $\begin{array}{c}9.137 * * * \\
(1.053)\end{array}$ & $\begin{array}{c}10.29 * * * \\
(0.937)\end{array}$ & & & \\
\hline IE & & & & & & & & & & $\begin{array}{c}8.115^{* * * *} \\
(2.334)\end{array}$ & $\begin{array}{c}7.815 * * * \\
(2.194)\end{array}$ & $\begin{array}{c}11.45^{* * * *} \\
(1.751)\end{array}$ \\
\hline GDPjt & $\begin{array}{c}-1.444 * * * \\
(0.298) \\
-2.31 \mathrm{e}- \\
05 * * \\
(1.01 \mathrm{e}-05)\end{array}$ & $\begin{array}{c}-1.493 * * * \\
(0.339) \\
-2.47 \mathrm{e}- \\
05^{* *} \\
(1.12 \mathrm{e}-05)\end{array}$ & $\begin{array}{c}-2.456 * * * \\
(0.495) \\
-6.12 \mathrm{e}- \\
05^{* *} \\
(2.59 \mathrm{e}-05)\end{array}$ & $\begin{array}{c}0.554 * * * \\
(0.178) \\
3.32 \mathrm{e}- \\
05 * * * \\
(5.33 \mathrm{e}-06)\end{array}$ & $\begin{array}{c}0.618 * * * \\
(0.178) \\
3.52 \mathrm{e}- \\
05 * * * \\
(4.81 \mathrm{e}-06)\end{array}$ & $\begin{array}{c}0.319 * \\
(0.169) \\
2.65 \mathrm{e}- \\
05 * * * \\
(4.68 \mathrm{e}-06)\end{array}$ & $\begin{array}{c}-3.438 * * * \\
(0.303) \\
-5.29 \mathrm{e}-06 \\
(8.47 \mathrm{e}-06)\end{array}$ & $\begin{array}{c}-3.394 * * * \\
(0.300) \\
-4.49 \mathrm{e}-06 \\
(8.51 \mathrm{e}-06)\end{array}$ & $\begin{array}{c}-3.602 * * * \\
(0.297) \\
\\
1.69 \mathrm{e}-06 \\
(8.06 \mathrm{e}-06)\end{array}$ & $\begin{array}{c}-1.058 * * * \\
(0.174) \\
-4.60 \mathrm{e}- \\
05 * * * \\
(1.56 \mathrm{e}-05)\end{array}$ & $\begin{array}{c}-0.988 * * * \\
(0.177) \\
-4.14 \mathrm{e}- \\
05 * * * \\
(1.53 \mathrm{e}-05)\end{array}$ & $\begin{array}{c}-1.230 * * * \\
(0.202) \\
-6.26 \mathrm{e}- \\
05 * * * \\
(2.01 \mathrm{e}-05)\end{array}$ \\
\hline FTA & $\mathrm{N}$ & $\mathrm{Y}$ & $\mathrm{Y}$ & $\mathrm{N}$ & $\mathrm{Y}$ & Y & $\mathrm{N}$ & $\mathrm{Y}$ & $\mathrm{Y}$ & $\mathrm{N}$ & Y & $\mathrm{Y}$ \\
\hline Language & $\mathrm{N}$ & $\mathrm{N}$ & $\mathrm{Y}$ & $\mathrm{N}$ & $\mathrm{N}$ & Y & $\mathrm{N}$ & $\mathrm{N}$ & $\mathrm{Y}$ & $\mathrm{N}$ & $\mathrm{N}$ & $\mathrm{Y}$ \\
\hline Distance & $\mathrm{N}$ & $\mathrm{N}$ & $\mathrm{Y}$ & $\mathrm{N}$ & $\mathrm{N}$ & $\mathrm{Y}$ & $\mathrm{N}$ & $\mathrm{N}$ & $\mathrm{Y}$ & $\mathrm{N}$ & $\mathrm{N}$ & $\mathrm{Y}$ \\
\hline Adjacency & $\mathrm{N}$ & $\mathrm{N}$ & $\mathrm{Y}$ & $\mathrm{N}$ & $\mathrm{N}$ & $\mathrm{Y}$ & $\mathrm{N}$ & $\mathrm{N}$ & $\mathrm{Y}$ & $\mathrm{N}$ & $\mathrm{N}$ & $\mathrm{Y}$ \\
\hline Constant & $\begin{array}{c}9.661 * * * \\
(1.335)\end{array}$ & $\begin{array}{c}9.829 * * * \\
(1.488)\end{array}$ & $\begin{array}{c}15.62 * * * \\
(2.864)\end{array}$ & $\begin{array}{c}-5.210 * * * \\
(1.528)\end{array}$ & $\begin{array}{c}-5.406 * * * \\
(1.502)\end{array}$ & $\begin{array}{l}-2.076 \\
(1.342)\end{array}$ & $\begin{array}{c}31.08 * * * \\
(2.589)\end{array}$ & $\begin{array}{c}30.69 * * * \\
(2.541)\end{array}$ & $\begin{array}{c}32.88 * * * \\
(2.669)\end{array}$ & $\begin{array}{c}8.376 * * * \\
(0.867)\end{array}$ & $\begin{array}{c}8.105 * * * \\
(0.764)\end{array}$ & $\begin{array}{c}10.98 * * * \\
(2.050)\end{array}$ \\
\hline No. of Name & 73 & 73 & 73 & 73 & 73 & 73 & 73 & 73 & 73 & 73 & 73 & 73 \\
\hline $\operatorname{AR}(2)$ & 0.97 & 0.97 & 0.95 & 1.68 & 1.73 & 1.50 & 0.83 & 0.83 & 0.76 & 1.62 & 1.61 & 1.59 \\
\hline $\mathrm{AR}(2) \mathrm{p}$-value & 0.330 & 0.332 & 0.344 & 0.092 & 0.084 & 0.133 & 0.404 & 0.405 & 0.446 & 0.105 & 0.107 & 0.113 \\
\hline Hansen Stat & 0.63 & 0.52 & 2.68 & 3.23 & 1.63 & 13.89 & 1.68 & 2.31 & 4.47 & 1.14 & 1.53 & 7.36 \\
\hline $\begin{array}{l}\text { Hansen } \\
\qquad \text {-value }\end{array}$ & 0.426 & 0.471 & 0.262 & 0.072 & 0.202 & 0.001 & 0.195 & 0.129 & 0.107 & 0.285 & 0.216 & 0.007 \\
\hline
\end{tabular}


Table 9: Robustness Check (2007-2018)

\begin{tabular}{|c|c|c|c|c|c|c|}
\hline & \multicolumn{3}{|c|}{ EXPORT } & \multicolumn{3}{|c|}{ IMPORT } \\
\hline & (1) & (2) & (3) & (4) & (5) & (6) \\
\hline $\mathrm{EX}(-1)$ & $\begin{array}{c}1.531 * * * \\
(0.348)\end{array}$ & $\begin{array}{c}1.581 * * * \\
(0.404)\end{array}$ & $\begin{array}{c}1.010 * * * \\
(0.205)\end{array}$ & & & \\
\hline $\mathrm{IM}(-1)$ & & & & $\begin{array}{c}0.658^{* * * *} \\
(0.177)\end{array}$ & $\begin{array}{c}0.587^{* * * *} \\
(0.196)\end{array}$ & $\begin{array}{c}0.976^{* * * *} \\
(0.202)\end{array}$ \\
\hline $\mathrm{TF}$ & $\begin{array}{c}-3.820 * * * \\
(1.353)\end{array}$ & $\begin{array}{c}-3.677^{* * * *} \\
(1.288)\end{array}$ & $\begin{array}{l}-0.262 \\
(0.819)\end{array}$ & $\begin{array}{c}1.582 \\
(1.228)\end{array}$ & $\begin{array}{c}1.159 \\
(0.851)\end{array}$ & $\begin{array}{l}-0.238 \\
(0.561)\end{array}$ \\
\hline GDPit & $\begin{array}{c}-3.517 * * * \\
(0.551)\end{array}$ & $\begin{array}{c}-3.667 * * * \\
(0.564)\end{array}$ & $\begin{array}{c}-2.161 * * * \\
(0.336)\end{array}$ & $\begin{array}{c}-1.587 * * * \\
(0.310)\end{array}$ & $\begin{array}{c}-1.313 * * * \\
(0.263)\end{array}$ & $\begin{array}{c}-1.772 * * * \\
(0.140)\end{array}$ \\
\hline GDPjt & $\begin{array}{c}-0.000368 * * \\
(0.000145)\end{array}$ & $\begin{array}{c}-0.000352^{* * *} \\
(0.000132)\end{array}$ & $\begin{array}{c}-2.58 \mathrm{e}-05 \\
(7.94 \mathrm{e}-05)\end{array}$ & $\begin{array}{l}0.000149 * \\
(7.64 \mathrm{e}-05)\end{array}$ & $\begin{array}{c}0.000121^{* *} \\
(4.95 \mathrm{e}-05)\end{array}$ & $\begin{array}{r}-1.98 \mathrm{e}-05 \\
(6.48 \mathrm{e}-05)\end{array}$ \\
\hline FTA & $\mathrm{N}$ & $\mathrm{Y}$ & $\mathrm{Y}$ & $\mathrm{N}$ & $\mathrm{Y}$ & $\mathrm{Y}$ \\
\hline Language & $\mathrm{N}$ & $\mathrm{N}$ & $\mathrm{Y}$ & $\mathrm{N}$ & $\mathrm{N}$ & Y \\
\hline Distance & $\mathrm{N}$ & $\mathrm{N}$ & $\mathrm{Y}$ & $\mathrm{N}$ & $\mathrm{N}$ & Y \\
\hline Adjacency & $\mathrm{N}$ & $\mathrm{N}$ & $\mathrm{Y}$ & $\mathrm{N}$ & $\mathrm{N}$ & $\mathrm{Y}$ \\
\hline Constant & $\begin{array}{c}38.30^{* * * *} \\
(4.432)\end{array}$ & $\begin{array}{c}38.68 * * * \\
(4.534)\end{array}$ & $\begin{array}{c}19.43 * * * \\
(4.309)\end{array}$ & $\begin{array}{c}11.77 * * * \\
(2.210)\end{array}$ & $\begin{array}{c}11.11^{* * * *} \\
(1.913)\end{array}$ & $\begin{array}{c}17.11 * * * \\
(1.631)\end{array}$ \\
\hline No. of Name & 73 & 73 & 73 & 73 & 73 & 73 \\
\hline $\mathrm{AR}(2)$ & 1.25 & 1.18 & 0.41 & 0.90 & 0.87 & 1.05 \\
\hline $\begin{array}{l}\mathrm{AR}(2) \\
\mathrm{p} \text {-value }\end{array}$ & 0.212 & 0.238 & 0.681 & 0.368 & 0.385 & 0.293 \\
\hline Hansen Stat & 0.39 & 0.44 & 1.09 & 1.85 & 1.4 & 4.45 \\
\hline Hansen p-value & 0.825 & 0.804 & 0.296 & 0.173 & 0.237 & 0.035 \\
\hline
\end{tabular}




\section{Discussion and Conclusion}

The paper examined the impact of TF on Vietnam's trade flows during the period 2007-2018. It estimated the TF through four effects: port, customs, infrastructure, and regulatory effects. This article chose the fixed effects model to analyze the impact of TF on the trade flows between Vietnam and its trading partners. Moreover, the System-GMM estimation tool was used to eliminate endogeneity problems due to the correlation between explanatory variables and error terms. This reinforced the accuracy of previous calculations. The TF coefficients are positive and statistically significant at the $1 \%$ level. Finally, to test the robustness of the empirical model, the TF indicators were replaced by four other indicators. At $1 \%$ level, TF was positive and statistically significant, and there was no difference in the presence of FTAs. This implies that TF is a necessary element for enhancing Vietnam's trade flows. The results showed that port, infrastructure, and regulatory improvements have caused Vietnam's trade flows to increase during the period 2007-2018. This finding is entirely consistent with previous studies that found TF contributed to improving trade. Customs clearance, however, has not been a factor in boosting trade flows (the CE variable was not statistically significant). Vietnam's trade flows were not significantly affected by FTAs. This is because most of the FTAs concluded by Vietnam are still in their implementation phase, including the TF measures they contain. This means that Vietnam's policy of increasing its trade linkages will not have a clear positive effect on the country's import and export activities until later when TF measures are implemented and fully enforced.

One of the reasons Vietnam has been active in the past two decades concluding FTAs and implementing a number of trade liberalization measures is to make the export sector highly competitive. They are critical to Vietnam's long-term growth. To maximize the effects of these policies and fully deliver on its commitment to reduce trade barriers, Vietnam, however, needs to improve its import environment. Obviously, the country cannot expect favorable conditions entering foreign markets and at the same time continue to impede imports. For one thing, in the name of reciprocity, the implementation of TFA commitments requires Hanoi to keep innovating and reforming its customs procedures. Customs authorities have a fundamental role to play in this transformation. But building a coordination mechanism between customs and state management agencies as part of implementing TFAs will remain a big challenge for Vietnam in the coming years. All the more as the temptation to protect domestic companies is likely to continue to inform its policies as more favorable customs procedures for imported goods facilitates the entry of foreign goods and therefore increases the competitive pressure on domestic manufacturers. Greater TF means more challenges for domestic enterprises as fierce competition from abroad mounts. The dilemma to be resolved is as follows: reform customs procedures according to TFA commitment and increase competition at home or slowly and haltingly change the rules and run the risk of hurting exports. This is one of the major challenges in TF reforms of Vietnam. Part of the answer and a first step in the right direction may be to make Vietnamese firms more competitive and streamline their oeprations. However, in order to maximize the benefits and opportunities which the expansion of trade links with major traders around the world, Vietnam also needs to improve the export capacity of domestic enterprises. This may require more FDI incentives for companies to invest in the country. When firms invest in Vietnam, they generally bring high-tech machinery and equipment and transfer technology know-how, something which the country badly needs. In turn, this exposure to new technologies promotes export activities and facilitates Vietnam's science and technology sector gradual integration into the world's science and technology and create conditions for fast and sustainable development of Vietnam enterprises. But more FDI also means more imports, either components, equipment or semi-finished products; hence the imperative need for the country to continue improving TF and ensure a smoother entry of goods. 


\section{- Recommendations}

TF is one of those terms that frequently features in FTAs; for good reasons. As has been stressed in this paper, if truly implemented, TF commitments by the parties to an FTA can bring many practical positive effects for those countries and increase the bottom line of businesses. For a start, well-managed TF can create social welfare and employment opportunities (Sakyi et al., 2017). For this to happen on a large scale in Vietnam, though, this means that the government needs to to resolve inspection issues, often a bottleneck, and strongly transform state management methods from pre-check to post-check by using risk management principles and assessing the level of legal compliance of both organizations and individuals. In addition, overlapping processes in the clearance process need to be thoroughly eliminated. As discussed earlier, due to the system of specialized inspection, multiple functional ministries are involved, creating costly and burdensome overlapping procedures. Reforming administrative procedure, minimizing post-clearance time and implementing automated customs supervision management system at all at all points of entry and exit are necessary steps toward full TF compliance.

Improving domestic infrastructure will also contribute to reducing logistics-related trade costs and creating new trade opportunities. While there has been progress as shown in the computations, there is much left to be done. Combining with improving port infrastructure, speeding up the shipping process will among other things help Vietnamese companies fully take advantage of the country's trade linkages (except for Singapore, no other ASEAN member state has concluded FTAs with both the EU and the US with which it also enjoys tariff preferential treatment under the Generalized System of Preferences). These preferential arrangements create many production location opportunities, all the more as the China-US trade war is causing some companies to relocate their production sites outside China. A clear strictly'enforced action plan to streamline customs procedures and improve the movement of goods within the country will go a long way in making Vietnam a FDI destination of choice for those companies.

\section{- Limitations}

This paper has limitations. For a start, it is based on data obtained from various statistical sources. The main advantage of these data sources is that these data warehouses are easily accessible and fairly reliable. As such, they are valuable tools to support the work of journalists and academia and expand research on global issues. They also help national policymakers to compare the progress of the projects they are in charge of and provid a tool to assess the advances of their economies. But these data warehouses also have certain limitations. Firstly, they cannot reflect all aspects of a country's economy. Secondly, their accuracy is still an issue as highlighted by the disparity between host country statistics and world organizations' databases. Therefore, when processing and estimating data, deviations are almsot inevitable and the actual situation may not fully be shown. Finally, since this research study only included bilateral FTAs, future research on the impact of TF on trade flows should focus on multilateral agreements such as, for example, the 15-member pan-Asian Regional Comprehensive Economic Partnership (RCEP), currently in its last round of negotiation, and the 11-member Comprehensive and Progressive Trans-Pacific Partnership (CPTPP), which, as its names indicates, include countries on both sides of the Atlantic.

\section{References}

ADB \& UNESCAP (2009). Designing and Implementing Trade Facilitation in Asia and the Pacific. Asian Development Bank and the United Nations. Retrieved March 10, 2020, from https://www.unescap.org/tid/ti_report2009/home.asp. 
ADB \& UNESCAP (2013). Designing and Implementing Trade Facilitation in Asia and the Pacific. Asian Development Bank and the United Nations. Retrieved March 10, 2020, from https://www.unescap.org/sites/default/files/0\%20-\%20Full\%20Report.pdf.

Chauffour, J. P., \& Maur, J. C. (2011). Preferential trade agreement policies for development.: A handbook. Washington, DC: World Bank.

Cheewatrakoolpong, K., \& Rujianakanoknad, J. (2011). The impact of AEC trade facilitation improvement on Thailand's goods in transit and inter-state trade. Chulalongkorn Journal of Economics 23, 19-37.

Doing Business (2016). Measuring Regulatory Quality and Efficiency. International Bank for Reconstruction and Development. Retrieved December 13, 2019, from https://www.doingbusiness.org/en/reports/global-reports/doing-business-2016

Dollar, D., \& Kraay, A. (2004). Trade, growth, and poverty. The Economic Journal, 114(493), F22-F49.

Dreger, C., \& Herzer, D. (2013). A further examination of the export-led growth hypothesis. Empirical Economics, 45(1), 39-60.

Fox, A. K., Francois, J. F., \& Londono-Kent, M. P. (2003). Measuring border crossing costs and their impact on trade flows: The United States-Mexican trucking case. GTAP Resource, No. 1282.

Goldin, I., \& Reinert, K. (2007). Globalization for development: trade, finance, aid, and migration and policy. Washington, DC: World Bank.

Hertel, T. W., Walmsley, T., \& Itakura, K. (2001). Dynamic effect of the "new age" free trade agreement between Japan and Singapore. Journal of Economic Integration, 16(4), 446-484.

Herzer, D. (2013) . Cross-country heterogeneity and the trade-income relationship. World Development, 44(c), 194-211.

Heshmati, A., \& Peng, S. (2012). International trade and its effects on economic performance in China. China Economic Policy Review, 1(2), 35-61.

Hollweg, C., \& Wong, M. H. (2009). Measuring regulatory restrictions in logistics services. ERIA Discussion Paper Series, No. 2009-14.

Jordaan, A. C. (2014). The impact of trade facilitation factors on South Africa's exports to a selection of African countries. Development Southern Africa, 31(4), 591-605.

Korinek, J., \& Sourdin, P. (2011). To what extent are high-quality logistics services trade facilitating? OECD Trade Policy Paper, No. 108.

Moïsé, E., \& Sorescu, S. (2013). Trade facilitation indicators: the potential impact of trade facilitation on developing countries'trade. OECD Trade Policy Paper, No. 144.

Nguyen, A. T., Nguyen, T. T., \& Hoang, G. T. (2016). Trade facilitation in ASEAN countries: Harmonisation of logistics policies. Asian-Pacific Economic Literature, 30(1), 120-134.

OECD (2017). Trade facilitation and the global economy: State of play in 2017. Paris: OECD Publishing.

OECD (2018). Trade facilitation and the global economy. Paris: OECD Publishing.

Otsuki, T. (2011). Quantifying the benefits of trade facilitation in ASEAN. OSIPP Discussion Paper, 2011E006.

Otsuki, T., Wilson, J. S., \& Sewadeh, M. (2001a). What price precaution? European harmonisation of aflatoxin regulations and African groundnut exports. European Review of Agricultural Economics, 28(2), 263-284.

Otsuki, T., Wilson, J. S., \& Sewadeh, M. (2001b). Saving two in a billion: Quantifying the trade effect of European food safety standards on African exports. Food Policy, 26(5), 495-514.

Pöyhönen, P. (1963). A tentative model for the volume of trade between countries. Welwirtschaftliches Archiv, 90(1), 93-99.

Pham, M.C., \& Vuong, Q.H. (2009). Kinh te Viet Nam: thang tram va dot pha. Hanoi: National Political Publisher. 
Pham, M. D., Mishra, D., Cheong, K. C., Arnold, J., Trinh, A. M., Ngo, H. T.N., \& Nguyen, H. T. P. (2013). Trade facilitation, value creation and competitiveness: policy implication for Vietnam's economic growth, summary report. World Bank Other Operational Studies 16786. Washington, DC: World Bank.

Ramanayake, S. S., \& Lee, K. (2015). Does openness lead to sustained economic growth? Export growth versus other variables as determinants of economic growth. Journal of the Asia Pacific Economy, 20(3), 345-368.

Ramos, L. M, Zarzoso, I. M., \& Suarez-Burgest, C. (2012). Trade policy versus trade facilitation: an application using "good old" tools. Economics E-Journal, 6(2012), 1-38.

Ravallion, M. (2001). Growth, inequality and poverty: Looking beyond averages. World Development, 29(11), 1803-1815.

Sakyi, D., Villaverde, J., \& Maza, A. (2015). Trade openness, income levels, and economic growth: The case of developing countries, 1970-2009. The Journal of International Trade \& Economic Development, 24(6), 860-882.

Sakyi, D., Villaverde, J., Maza, A., \& Bonuedi, I. (2017). The effects of trade and trade facilitation on economic growth in Africa. African Development Review, 29(2), 2017, 350361

Sakyi, D., Bonuedi, I., \& Opoku, E. E. (2018). Trade facilitation and social welfare in Africa. Journal of African Trade, 5(2018), 35-53.

Tinbergen, J. (1962). Sharing the world economy: Suggestions for an international economic policy. New York: Twentieth Century Fund.

Tuffour, A. J., Balchin, N., Calabrese L., \& Mendez-Parra, M. (2016). Trade Facilitation and Economic Transformation in Africa. Retrieved March 15, 2020, from http://set.odi.org/wpcontent/uploads/2016/03/SET-ACET-ATF-Trade-Facilitation-Paper.pdf

UNCTAD (2001). E-commerce and Development Report. New York and Geneva: United Nations. $\quad$ Retrieved $\quad$ February 19, 2020, from https://unctad.org/en/Docs/ecdr2001overview_en.pdf.

Vuong, Q. H., \& Napier, K. N. (2014). Resource curse or destructive creation in transition: Evidence from Vietnam's corporate sector. Management Research Review, 37(7), 642-657.

Vuong, T. T., Semerak, V., \& Vuong, Q. H. (2019). The Vietnamese economy at the crossroads, in Macdonald, R. (Ed.) Southeast Asia and the ASEAN Economic Community (p. 91-143). Palgrave Macmillan.

Walkenhorst, P., \& Yasui, T. (2003). Quantitative methods for assessing the effects of non-tariff measures and trade facilitation. Paris: OECD Publishing.

Walmsley, T. L., \& Minor, P. (2016). Willingness to pay in CGE models: Estimating the benefits of improved customs efficiencies within the WTO trade facilitation agreement. Working Paper Rev2. Washington, DC: World Bank.

Wilson, J. S. (2003). Trade facilitation and economic development: Measuring the impact. Policy Research Working Paper 2988, Washington, DC: World Bank.

Wilson, J. S., Mann, C., \& Otsuki, T. (2004). Assessing the potential benefit of trade facilitation: A global perspective. Policy Research Working Paper 3224, Washington, DC: World Bank.

Winters, L. A., McCulloch. N., \& McKay, A. (2004). Trade liberalization and poverty: The evidence so far. Journal of Economic Literature, 42(1), 72-115.

World Bank. (2017). Trade Logistics and Facilitation Brochure. Washington, DC: World Bank. 
Chính, P. M., \& Hoàng, V. Q. (2009). Kinh tế Việt Nam: Thăng trầm và đột phá. NXB Chính trị Quốc gia, Hà Nội. 